\title{
Epidemiological study of the lung function of workers at a factory manufacturing polyvinylchloride
}

\author{
M H LLOYD, S GAULD, L COPLAND AND C A SOUTAR \\ From the Institute of Occupational Medicine, Edinburgh EH8 9SU, UK
}

\begin{abstract}
A preliminary epidemiological study has been carried out to investigate a report that some men working in a factory manufacturing polyvinylchloride (PVC) had abnormally low values of the single breath diffusing capacity for carbon monoxide ( $\mathrm{T}_{\mathrm{LCO}}$ ). All 265 present and past employees of the PVC factory were studied, together with 219 men from the workforce of a nearby foundry. Each man's $T_{L} C O$ was measured and a smoking history and detailed occupational history obtained. The distribution of standardised $T_{L} C O$ results from all persons examined was symmetrical and did not indicate an unexpectedly high proportion of men with clinically important impairment of $\mathrm{T}_{\mathrm{L} C O}$. The results of a case-control study showed that, having allowed for age, height, weight, and smoking habit, $\mathrm{T}_{\mathrm{L}} \mathrm{CO}$ was associated with a history of working in the PVC factory before 1975 (when levels of vinylchloride monomers (VCM) were much higher than subsequently), and slightly associated with working in jobs where exposure to VCM was likely to have been highest. The men with low $T_{L} C O$ also tended to have smoked more heavily than controls. The relative importance of occupational factors and smoking in relation to low $\mathrm{T}_{\mathrm{LCO}}$ is not clear, but the results give some support to the hypothesis that work in the PVC factory before 1975 entailed exposure to a substance that caused impairment of lung function in a small number of men.
\end{abstract}

The management and occupational physician of a factory making polyvinylchloride (PVC) had become concerned over an apparent excess in their workforce of men with impairment of the single breath transfer factor for carbon monoxide $\left(\mathrm{T}_{\mathrm{L} C \mathrm{C}}\right)$. The present study was planned to determine whether there was such an excess of men with low values of $T_{L} C O$ in the workforce, and to make a preliminary assessment of whether low $\mathrm{T}_{\mathrm{L}} \mathrm{CO}$ might be related to occupational factors.

The factory had been in operation since 1969 and produced PVC powder from vinylchloride monomer gas (VCM). All men who had worked at the factory, whether or not they were currently employed there, were invited to participate in the study. A sample of men working in a nearby foundry were also invited to participate; they had been exposed to the same environmental conditions outside the workplace and were included in order to augment the number of men in the study who had not been exposed to possible hazards in the PVC factory.

Received 28 February 1983

Accepted 9 May 1983

\section{Methods}

SELECTION OF SURVEY POPULATION

All 177 men currently employed at the PVC factory were invited to take part and attempts were made to trace and invite all the $\mathbf{2 6 3}$ former employees. At the foundry, the study was confined to 285 men selected randomly from the 1085 current male employees. The number of men at the foundry aged under 25 was limited to 15 to take account of a disproportionately large number of young men in the foundry population compared with the PVC workers and to provide a group of similar size to the 13 PVC workers of this age. Apart from this, selection did not take account of age.

\section{MEDICAL SURVEY}

The medical survey team visited the factories and recorded a full occupational history since leaving school for each man. Trained personnel using a questionnaire which was a modified version of the Medical Research Council questionnaire of respiratory symptoms ${ }^{1}$ recorded details of each man's smoking history. Additional questions were related to age of starting smoking and the number of 
cigarettes smoked during a man's maximum smoking period.

Measurements of single breath gas transfer factor for carbon monoxide were carried out on all men using the breathholding method ${ }^{2}$ based on the modified Krogh technique (transfer test B; P K Morgan Ltd, Chatham, Kent). The mean of two measurements was used in the subsequent analysis. All PVC factory employees had forced expiratory volume in one second $\left(\mathrm{FEV}_{1}\right)$ and forced vital capacity (FVC) measured using an electronic dry rolling seal spirometer (Ohio 800). The best of three technically satisfactory measurements was used for the analysis. Approval was not obtained for FEV 1 and FVC measurements in the foundry workers.

\section{METHODS OF ANALYSIS}

\section{Analysis of data from the total survey population}

The data were studied initially by summary descriptive statistics and by multiple linear regression analysis of lung function taking into account age, height, weight, and smoking habit. Men were assigned to one of three smoking categories; lifelong non-smoker, current smoker, and ex-smoker. The two smoking groups included smokers of pipes, cigars, and hand-rolled cigarettes but the majority smoked manufactured cigarettes.

In the regression model used for both $\mathrm{T}_{L} \mathrm{CO}$ and $\mathrm{FEV}_{1}$ different intercepts and age slopes were allowed for the three smoking groups, non-smokers, current smokers, and ex-smokers. This means that the estimated effects of age were not constrained to be the same necessarily in the three smoking habit groups.

The relation between a man's observed and predicted lung function values was expressed as a standardised residual (SR). This is defined by the equation:

$$
\mathrm{SR}=\frac{\text { (observed value }- \text { value predicted from fitted equation) }}{\text { (estimated standard deviation of the prediction) }}
$$

The distribution of $F E V_{1}$ and $T_{L}$ CO SR values of the whole population was examined.

\section{Case-control study}

For each lung function variable, those men with the largest negative SR value were chosen as cases. Two groups of controls were selected randomly, firstly, from those men whose SRs were clustered around zero ("average" controls) and, secondly, from those with largest positive SRs ("healthiest" controls). Two groups were chosen because men with average values may have included some whose lung function had been slightly affected by noxious influences, whereas those with very high values were least likely to have been affected by noxious influences but
Table 1 Classification of all jobs at PVC factory into six broad occupational groups.

\begin{tabular}{|c|c|}
\hline $\begin{array}{l}\text { Broad occupational } \\
\text { group }\end{array}$ & Jobs included in group \\
\hline $\begin{array}{l}1 \\
2 \\
3\end{array}$ & $\begin{array}{l}\text { All men working in reactors } 1 \text { and } 2^{*} \\
\text { Dryer room B operators } \dagger \\
\text { Dryer room Lead, A and A/E } \\
\text { operators }\end{array}$ \\
\hline 4 & $\begin{array}{l}\text { Warehousemen, maintenance staff, } \\
\text { laboratory staff, and drivers } \ddagger\end{array}$ \\
\hline 5 & $\begin{array}{l}\text { General staff who visit plant, such as } \\
\text { shift supervisors and foremen }\end{array}$ \\
\hline 6 & Management and office staff \\
\hline
\end{tabular}

${ }^{*}$ Men most likely to have been exposed to high concentrations of VCM in the past.

tMen engaged in the bagging of PVC and probably exposed to higher concentrations of dust than other workers in the dryer buildings.

‡Men potentially exposed to all raw materials and products.

might include men who were highly resistant to these influences.

Cases were initially compared with the rest of the survey population in order to identify any systematic differences in age, smoking habit, and employment status. Then the occupational and smoking histories of cases and controls were examined and compared. Smoking histories were classified as they were for the total population, but additional information about the number of cigarettes smoked and the age of starting smoking was analysed in the case-control study. Broad occupational categories were defined for the PVC factory (table 1) and for the foundry, and the total number of years spent by cases and controls in each occupational category was calculated. Additional information was available for PVC employees in relation to exposure to emulsion polymer (which has a smaller particle size than suspension polymer and which was manufactured at the factory between 1971 and 1974) and employment in the factory before 1975 when levels of VCM were much higher than the currently permitted levels. From the full occupational history the number of years spent in potentially "noxious" industries (such as coal, steel, chemicals, and a miscellaneous group of industries in which exposure to noxious compounds might have occurred) was recorded.

In the analysis Fisher's exact test, the chi-squared test for $2 \times 2$ contingency tables, and the chisquared test for linear trend were used where appropriate.

\section{Results}

A total of 488 men was seen, consisting of 165 current PVC factory employees $(93 \%$ of those who were asked to participate), 102 PVC former employees (39\% of those invited), and 221 foundry employees (78\% of those invited). Four men (two PVC and two foundry) were excluded from the 


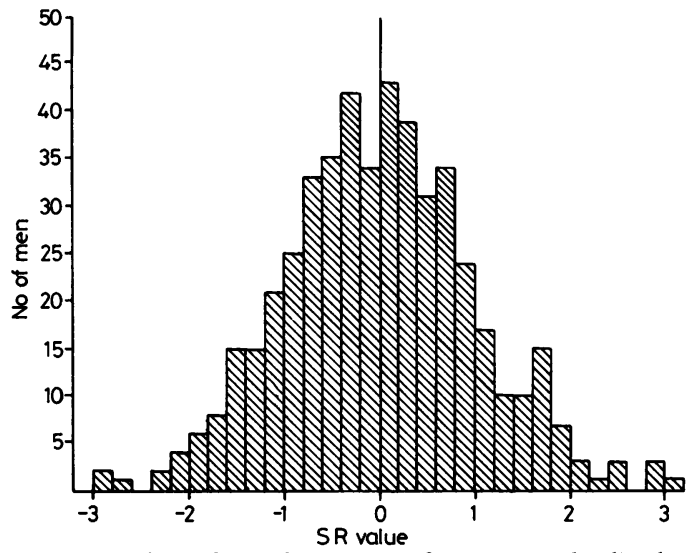

Fig 1 Number of men by ranges of $T_{L}$ co standardised residuals.

$\mathrm{T}_{\mathrm{LCO}}$ analysis because of incomplete data, and to the final analysis was based on 484 men. As FEV , and FVC measurements were not obtained from three PVC factory workers and all 221 foundrymen this analysis was based on 264 men.

The distributions of standardised residual values of $T_{L C O}$ and $F E V_{1}$ for the total survey population after allowing for age, height, weight, and smoking habit were fairly symmetrical and conformed approximately to Normal distributions (figs 1 and 2), although for FEV, there were slightly more extreme negative values than extreme positive values.

\section{SELECTION OF CASES AND CONTROLS}

A threshold $S R$ value for $T_{L}$ CO of -1.5 supplied 31 men, a number that was considered large enough to form a study group. A control group of 31 men was selected randomly from those men with $S R$ values between -0.25 and +0.75 inclusive $\left(T_{L}\right.$ CO average controls). A second control group of 31 "extra healthy" men was selected randomly from those with SR values in excess of +0.75 ( $\mathrm{T}_{\mathrm{L}}$ CO healthiest con-

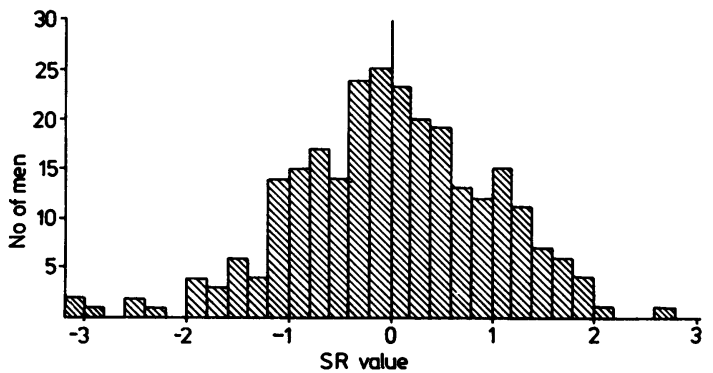

Fig 2 Number of men by ranges of FEV, standardised residuals.
Table 2 Features of $T_{L}$ co cases, controls, and total survey population. Mean (and standard deviations) of age, height, weight and $T_{L}$ CO

\begin{tabular}{|c|c|c|c|c|}
\hline \multirow[t]{2}{*}{ No of men } & \multicolumn{3}{|c|}{$T_{L}$ CO groups } & \multirow{2}{*}{$\begin{array}{l}\text { Total } \\
\text { survey } \\
\text { population } \\
(484)\end{array}$} \\
\hline & $\begin{array}{l}\text { Cases } \\
(31)\end{array}$ & $\begin{array}{l}\text { Controls } \\
\text { (average) } \\
(31)\end{array}$ & $\begin{array}{l}\text { Controls } \\
\text { (healthiest) } \\
(31)\end{array}$ & \\
\hline $\begin{array}{l}\text { Age }(y): \\
\text { Mean } \\
\text { (SD) }\end{array}$ & $\begin{array}{c}41 \cdot 8 \\
(10 \cdot 2)\end{array}$ & $\begin{array}{c}42 \cdot 3 \\
(12 \cdot 5)\end{array}$ & $\begin{array}{c}40 \cdot 3 \\
(11 \cdot 3)\end{array}$ & $\begin{array}{c}42.2 \\
(11.9)\end{array}$ \\
\hline $\begin{array}{l}\text { Height }(\mathrm{cm}): \\
\text { Mean } \\
\text { (SD) }\end{array}$ & $\begin{array}{c}176 \cdot 1 \\
(7 \cdot 1)\end{array}$ & $\begin{array}{c}174.0 \\
(6.6)\end{array}$ & $\begin{array}{c}173.9 \\
(5.6)\end{array}$ & $\begin{array}{c}173 \cdot 8 \\
(7 \cdot 0)\end{array}$ \\
\hline $\begin{array}{l}\text { Weight }(\mathrm{kg}) \text { : } \\
\text { Mean } \\
\text { (SD) } \\
\mathrm{T}_{\mathrm{LCO}} \\
(\mathrm{m} / \mathrm{min} \mathrm{mm} \mathrm{Hg})\end{array}$ & $\begin{array}{c}82 \cdot 7 \\
(13 \cdot 3)\end{array}$ & $\begin{array}{c}84 \cdot 9 \\
(18 \cdot 5)\end{array}$ & $\begin{array}{l}79 \cdot 2 \\
(9 \cdot 5)\end{array}$ & $\begin{array}{c}80 \cdot 2 \\
(12 \cdot 6)\end{array}$ \\
\hline $\begin{array}{l}\text { Mean } \\
\text { (SD) }\end{array}$ & $\begin{array}{l}22 \cdot 2 \\
(4 \cdot 1)\end{array}$ & $\begin{array}{l}31 \cdot 8 \\
(2 \cdot 9)\end{array}$ & $\begin{array}{l}37 \cdot 3 \\
(4 \cdot 3)\end{array}$ & $\begin{array}{l}30 \cdot 5 \\
(5 \cdot 9)\end{array}$ \\
\hline
\end{tabular}

trols). Similarly, 30 men with an FEV, SR value of less than $-1 \cdot 1$ were selected as $F E V_{1}$ cases and two groups of controls $\left(\mathrm{FEV}_{1}\right.$ average controls and $\mathrm{FEV}$, healthiest controls) were chosen from those men with SR value between -0.25 and +0.75 and in excess of +0.75 respectively.

CLINICAL FEATURES OF CASES, CONTROLS, AND THE TOTAL POPULATION

The general features of $\mathrm{T}_{\mathrm{LCO}} \mathrm{and} \mathrm{FEV}_{1}$ cases, controls, and the total population are shown in tables 2 and 3 . The mean age of the $\mathrm{T}_{\mathrm{L}} \mathrm{CO}$ case and control groups were similar.

Observed $\mathrm{T}_{\mathrm{LCO}}$ and $\mathrm{FEV}_{1}$ values of the cases were also expressed as a percentage of values predicted on the basis of Cotes' regression equation. ${ }^{3}$ Fifteen of the $31 \mathrm{~T}_{\mathrm{LCO}}$ cases had $\mathrm{T}_{\mathrm{LCO}}$ values below $70 \%$ of their predicted values; four were below $60 \%$. Twelve of these 15 men were PVC workers and three were foundrymen. Nineteen of the $\mathbf{3 1}$ cases were from the PVC factory and four of these had evidence of airflow obstruction $\left(\mathrm{FEV}_{1}<\right.$ $80 \%$ and $\mathrm{FEV}_{1} / \mathrm{FVC}<70 \%$ ); examination of forced expiratory flow-volume loops suggested that a further seven might have mild airflow obstruction. In the remaining eight the low $\mathrm{T}_{\mathrm{L}} \mathrm{CO}$ appeared to be an isolated abnormality.

Of the $30 \mathrm{FEV}_{1}$ cases, 13 had observed $\mathrm{FEV}_{1}$ values below $80 \%$ of their predicted values and 10 of these men had $\mathrm{FEV}_{\mathrm{l}} / \mathrm{FVC}$ ratios below $70 \%$ suggesting airflow obstruction. Seven of the $\mathrm{FEV}_{1}$ cases also qualified for inclusion as $\mathrm{T}_{\mathrm{L}} \mathrm{CO}$ cases.

\section{OCCUPATIONAL HISTORIES}

Analysis of employment status showed that 19 of the $T_{\text {LCO }}$ cases worked or had worked at the PVC factory and 12 were foundrymen, but this difference could easily have arisen by chance. Most workers 
Table 3 Features of FEV, cases, controls, and total survey population. Mean (and standard deviations) of age, height, weight, $T_{L} C O, F E V_{1}$ and FVC

\begin{tabular}{|c|c|c|c|c|}
\hline \multirow[t]{2}{*}{ No of men } & \multicolumn{3}{|c|}{$T_{L}$ CO groups } & \multirow{2}{*}{$\begin{array}{l}\text { Total } \\
\text { survey } \\
\text { population } \\
(264)\end{array}$} \\
\hline & $\begin{array}{l}\text { Cases } \\
(30)\end{array}$ & $\begin{array}{l}\text { Controls } \\
\text { (average) } \\
(30)\end{array}$ & $\begin{array}{l}\text { Controls } \\
\text { (healthiest) } \\
\text { (30) }\end{array}$ & \\
\hline $\begin{array}{l}\text { Age (y): } \\
\text { Mean } \\
\text { (SD) }\end{array}$ & $\begin{array}{c}43 \cdot 3 \\
(11 \cdot 0)\end{array}$ & $\begin{array}{c}41 \cdot 3 \\
(12 \cdot 5)\end{array}$ & $\begin{array}{c}42 \cdot 1 \\
(12 \cdot 0)\end{array}$ & $\begin{array}{c}42 \cdot 2 \\
(11 \cdot 8)\end{array}$ \\
\hline $\begin{array}{l}\text { Height }(\mathrm{cm}) \text { : } \\
\text { Mean } \\
\text { (SD) }\end{array}$ & $\begin{array}{c}176 \cdot 0 \\
(7 \cdot 4)\end{array}$ & $\begin{array}{c}174 \cdot 5 \\
(6 \cdot 6)\end{array}$ & $\begin{array}{c}175.9 \\
(8.0)\end{array}$ & $\begin{array}{c}174 \cdot 3 \\
(7 \cdot 1)\end{array}$ \\
\hline $\begin{array}{l}\text { Weight }(\mathrm{kg}) \text { : } \\
\text { Mean } \\
\text { (SD) }\end{array}$ & $\begin{array}{c}82 \cdot 2 \\
(13 \cdot 3)\end{array}$ & $\begin{array}{c}78 \cdot 4 \\
(10 \cdot 1)\end{array}$ & $\begin{array}{c}80 \cdot 4 \\
(11 \cdot 5)\end{array}$ & $\begin{array}{c}80 \cdot 4 \\
(12 \cdot 3)\end{array}$ \\
\hline $\begin{array}{l}\text { FEV (1): } \\
\text { Mean } \\
\text { (SD) }\end{array}$ & $\begin{array}{c}2.7 \\
(0.7)\end{array}$ & $\begin{array}{c}3.9 \\
(0.7)\end{array}$ & $\begin{array}{c}4.5 \\
(0.8)\end{array}$ & $\begin{array}{c}3.7 \\
(0.9)\end{array}$ \\
\hline $\begin{array}{l}\text { FVC (1): } \\
\text { Mean } \\
\text { (SD) }\end{array}$ & $\begin{array}{c}4 \cdot 1 \\
(0 \cdot 9)\end{array}$ & $\begin{array}{c}5 \cdot 1 \\
(0 \cdot 8)\end{array}$ & $\begin{array}{c}5.9 \\
(0.9)\end{array}$ & $\begin{array}{c}4.9 \\
(1 \cdot 0)\end{array}$ \\
\hline $\begin{array}{l}\mathrm{T}_{\mathrm{LCO}} \mathrm{CO} \\
(\underset{\mathrm{ml}}{\mathrm{Mean}} \mathrm{mm} \mathrm{Hg}): \\
\text { (SD) }\end{array}$ & $\begin{array}{l}29 \cdot 1^{*} \\
(6 \cdot 8)^{*}\end{array}$ & $\begin{array}{l}32 \cdot 3 \\
(6 \cdot 0)\end{array}$ & $\begin{array}{l}31 \cdot 3 \\
(6 \cdot 5)\end{array}$ & $\begin{array}{l}30 \cdot 5 \dagger \\
(6 \cdot 1) \dagger\end{array}$ \\
\hline
\end{tabular}

*Value based on 29 observations.

†Value based on 262 observations.

had worked in more than one type of job and in more than one broad occupational category during their employment with the companies. More cases than controls had worked in jobs in category 1 (on or near the reactors) at the PVC factory; 11 of 31 cases $(35 \%)$ had worked in this category compared with 10 of 62 controls $(16 \%)$ and this disproportion is significant at the $7 \%$ level (table 4). No suggestive differences were seen in the pattern of employment of FEV, cases and controls.

More cases than controls had worked at the PVC
Table 5 Smoking habits of $T_{L}$ co cases, controls, and total survey population. Number of men in each smoking category with percentages in parentheses

\begin{tabular}{lrrrr}
\hline & $\begin{array}{l}\text { Non- } \\
\text { smoker }\end{array}$ & $\begin{array}{l}\text { Current } \\
\text { smoker }\end{array}$ & Ex-smoker & Total \\
\hline $\begin{array}{l}\text { Cases } \\
\begin{array}{c}\text { Controls } \\
\text { (average) }\end{array}\end{array}$ & $3(9 \cdot 7)$ & $20(64 \cdot 5)$ & $8(25 \cdot 8)$ & 31 \\
$\begin{array}{c}\text { Controls } \\
\text { (healthiest) }\end{array}$ & $7(22.6)$ & $15(48.4)$ & $9(29 \cdot 0)$ & 31 \\
$\begin{array}{c}\text { Total survey } \\
\text { population }\end{array}$ & $109(22 \cdot 5)$ & $234(48.4)$ & $141(29 \cdot 1)$ & 484 \\
\hline
\end{tabular}

factory before 1 January 1975 , when levels of vinylchloride were much higher than at present. Seventeen of the $19 \mathrm{~T}_{\mathrm{L}} \mathrm{CO}$ cases who had worked at the PVC factory had been employed before 1975 whereas only five of the 15 healthiest controls and 11 of the 13 average controls had been. The difference between cases and healthiest controls was significant $(p<0.002)$, and the increase in the proportion of men with pre- 1975 employment in the PVC factory for the three groups over healthiest controls, average controls, and cases was also statistically significant $(p<0.001)$. Analysis of the duration of employment of men within different age groups showed that pre-1975 working was seen in both younger and older men. A similar analysis of FEV , cases and controls and foundry $T_{L} C O$ cases failed to show any significant differences in relation to working before 1975 . These findings suggest that some factor or factors associated with working at the PVC factory before 1975 had caused impairment of $\mathrm{T}_{\mathrm{LCO}}$ in some men.

There was no difference in the numbers of $\mathrm{T}_{\mathrm{LCO}}$ or FEV, cases and controls who had been exposed

Table 4 Numbers of men who had spent some time in each occupational group. (Mean time (years) spent in each occupational group)

\begin{tabular}{|c|c|c|c|c|c|c|c|c|c|c|c|c|c|c|}
\hline & \multirow{2}{*}{$\begin{array}{l}\text { No of } \\
\text { men }\end{array}$} & \multicolumn{13}{|c|}{ Occupational groups } \\
\hline & & 1 & 2 & 3 & 4 & 5 & 6 & 7 & 8 & 9 & 10 & 11 & 12 & 13 \\
\hline \multicolumn{15}{|l|}{ Cases: } \\
\hline PVC workers & 19 & $\begin{array}{l}11 \\
(2 \cdot 7)\end{array}$ & $\begin{array}{l}11 \\
(0 \cdot 6)\end{array}$ & $\begin{array}{l}4 \\
(7 \cdot 6)\end{array}$ & $\begin{array}{l}4 \\
(9.0)\end{array}$ & $\begin{array}{l}2 \\
(9 \cdot 7)\end{array}$ & - & $\begin{array}{l}1 \\
(7 \cdot 0)\end{array}$ & & & $\begin{array}{l}5 \\
(5 \cdot 6)\end{array}$ & & $\begin{array}{l}1 \\
(1 \cdot 4)\end{array}$ & \\
\hline Foundrymen & 12 & & & & & & & $\begin{array}{l}4 \\
(7 \cdot 3)\end{array}$ & $\begin{array}{l}2 \\
(3 \cdot 0)\end{array}$ & $\begin{array}{l}5 \\
(12 \cdot 3)\end{array}$ & $\begin{array}{l}7 \\
(4.0)\end{array}$ & $\begin{array}{l}2 \\
(3 \cdot 2)\end{array}$ & $(11.4)$ & $\begin{array}{l}1 \\
(1 \cdot 0)\end{array}$ \\
\hline \multicolumn{15}{|l|}{ Average controls: } \\
\hline PVC workers & 13 & $\begin{array}{l}4 \\
(7 \cdot 0)\end{array}$ & $\begin{array}{l}7 \\
(0 \cdot 7)\end{array}$ & $\begin{array}{l}1 \\
(6 \cdot 8)\end{array}$ & $\begin{array}{l}5 \\
(6 \cdot 0)\end{array}$ & $\begin{array}{l}1 \\
(12 \cdot 3)\end{array}$ & - & - & - & - & - & - & - & - \\
\hline Foundrymen & 18 & & & & & & & $\begin{array}{l}3 \\
(4 \cdot 6)\end{array}$ & $\begin{array}{l}5 \\
(16 \cdot 1)\end{array}$ & $\frac{1}{(30 \cdot 4)}$ & $\begin{array}{l}9 \\
(9 \cdot 4)\end{array}$ & $\begin{array}{l}1 \\
(7 \cdot 4)\end{array}$ & $\begin{array}{l}5 \\
(10 \cdot 6)\end{array}$ & $\begin{array}{l}1 \\
(2 \cdot 5)\end{array}$ \\
\hline \multicolumn{14}{|l|}{ Healthiest controls: } & - \\
\hline Foundrymen & 16 & $(3 \cdot 0)$ & $(1 \cdot 0)$ & $(10 \cdot 8)$ & $(7 \cdot 3)$ & $(3 \cdot 3)$ & $(1 \cdot 7)$ & $\begin{array}{l}5 \\
(13 \cdot 4)\end{array}$ & $\begin{array}{l}3 \\
(4 \cdot 5)\end{array}$ & $\begin{array}{l}3 \\
(12 \cdot 7)\end{array}$ & $\begin{array}{l}(4 \cdot 0) \\
8 \\
(12 \cdot 5)\end{array}$ & $\begin{array}{l}(0 \cdot 5) \\
-\end{array}$ & $\begin{array}{l}6 \\
(11 \cdot 6)\end{array}$ & - \\
\hline
\end{tabular}

Note: Occupational groups 1-6 refer to PVC factory (see table 1) and 7-13 jobs at the foundry-that is, 7 work on or near the furnaces; 8 sand work and shot-blasting: 9 grinding and welding: 10 general jobs; 11 painting and dipping; 12 casting work; 13 fettling. 


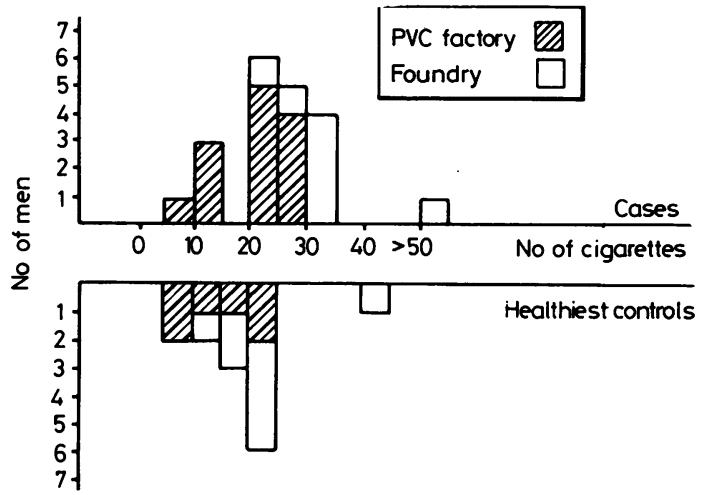

Fig 3 Number of cigarettes smoked a day at weekends among current smoking $T_{L}$ co cases and healthiest controls.

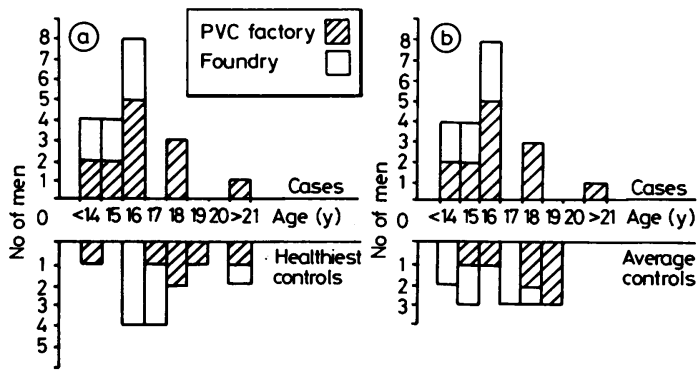

Fig 4 (a) Age at start of cigarette smoking among $T_{L}$ CO cases and healthiest controls who were current smokers. (b) Age at start of cigarette smoking among $T_{L} C O$ cases and average controls who were current smokers.

to emulsion polymer at the PVC factory.

No evidence was obtained that the observed difference between cases and controls could be explained on the basis of previous employment in industries other than the PVC factory or foundry.

\section{SMOKING HABITS OF CASES AND CONTROLS}

Whereas the procedure for selection of cases and controls had taken account of whether a man smoked, it was found that the $T_{L} C O$ cases had tended to smoke more than controls. A slightly higher proportion of $T_{L C O}$ cases $(65 \%)$ were current cigarette smokers than either group of controls (on average $48 \%$ ) (table 5), and more of these cases smoked 25 cigarettes or more at the weekend than the healthiest controls (fig 3). Weekday smoking followed a similar but statistically insignificant pattern. The $T_{L C O}$ cases tended to have started smoking at an earlier age than controls (fig 4).

\section{Discussion}

Whereas exposure to PVC dust has been shown to be related to a mild reduction of lung function and chest $x$ ray abnormalities, ${ }^{45}$ less is known about the pulmonary effects of exposure to VCM. There have been some case reports of men exposed to VCM who had impairment of lung function, particularly $\mathrm{T}_{\mathrm{LCO}}{ }^{67}$ and changes in lung histology have been reported. ${ }^{68}$

The present study was designed as a preliminary examination of whether an undue number of men at this PVC factory had impaired $\mathrm{T}_{\mathrm{LCO}}$, and whether such impairment was likely to be related to their occupation. We have found no evidence of a substantial excess of men with impairment of the $T_{L} c 0$, although low $T_{L} C O$ values were found in a few men, as might be expected in any large population of workers. After allowing for other factors, however, those men with the lowest $T_{L}$ Co tended to have worked more often than would be expected at the PVC factory before 1975 , a date before which concentrations of VCM were known to have been much higher than subsequently; these men also tended slightly to have worked in the jobs where the highest concentrations of VCM were found.

This evidence gives some support to the hypothesis that work in the PVC factory entailed exposure to one or more substances that caused impairment of lung function in a small number of men. The most likely substance is VCM, on which suspicion has previously been cast by case reports of vinylchloride workers with impairment of gas transfer factor, but in which proof of association has been lacking. ${ }^{67}$ It is also possible that exposure to respirable PVC dust may have contributed to the low gas transfer factors although there was little positive evidence for this in our study. PVC dust has been shown in other studies to be associated with impairment of other aspects of lung function (though not the gas transfer factor) and slight chest $x$ ray abnormalities. ${ }^{4} 5$

There was little evidence to support, as an alternative hypothesis, the suggestion that the workforce recruited in the early years of production included an excess of men with poor respiratory health at the time of entry to the factory. The $\mathrm{FEV}_{1}$, a more sensitive indication of the common types of chronic respiratory illness, was not found to be particularly adversely affected in men working in the factory before 1975 .

The selection of cases took into account whether a man smoked, but even after allowing for this, the cases with low $T_{L} C O$ tended to have smoked slightly more than the controls, and notably the age at which a man started to smoke appeared to be related to low $\mathrm{T}_{\mathrm{L}}$ CO. The relative contributions towards impairment of $T_{L} C O$ of smoking and of occupational factors are not clear from this study, but it is possible 
that both were important. The men with the lowest $T_{L}$ CO values selected as cases were not all necessarily suffering from lung disease but among them were 15 men whose $T_{L} C O$ was less than $70 \%$ of the value predicted by published normal values, a level which probably indicates the presence of disease. In eight of the 19 cases who had worked at the PVC factory the low $\hat{\mathrm{T}}_{\mathrm{LCO}}$ was an isolated abnormality, a pattern unlikely to be the result of damage from smoking and which is usually associated with interstitial lung disease or disturbance of pulmonary perfusion.

Reports of both animal and clinical studies give further support to the suggestion that exposure to VCM might have been an important causative factor. Animal studies have shown that exposure to high levels of VCM leads to pulmonary fibrosis, the changes being most severe in the animals which had been exposed for the longest time. ${ }^{9}$ There have been isolated case reports of individuals with interstitial lung disease who had been employed in the manufacture of PVC and who had, therefore, been exposed to VCM. ${ }^{6}{ }^{10}$ Hunter et al described six such workers, three of whom had died from liver disease related to VCM exposure ${ }^{8}$; none of the six had respiratory symptoms, three had abnormal chest $x$ ray films, and one an abnormal $\mathrm{T}_{L} \mathrm{CO}$, but the lung histology from all six men showed a similar picture with the presence of an inflammatory interstitial infiltrate.

Diligent attempts were made to contact all men who had worked at the PVC factory but response was low $(39 \%)$. If the men not examined had included either an excess or deficiency of men with impaired gas transfer factor compared with the population examined then the analysis of the distribution of values among the population seen would be unrepresentative to that extent.

We conclude that this preliminary study has shown no evidence that current working conditions in either factory have caused impairment of lung function but it does give some support to the hypothesis that work in the PVC factory before
1975 entailed exposure to a substance that caused impairment of lung function in a small number of men. Further work including clinical studies of affected men would be necessary to characterise this impairment and to explore more fully the relations with occupational and other factors.

This study was carried out with the full cooperation of the management and workforce of Vinatex Limited to whom we are grateful for financial support. We thank the management and employees of the foundry for their generous cooperation in the study and the medical officers at Vinatex and British Steel for their help. We also thank Dr A Seaton and Dr M Jacobson for their advice. Further details of the results of the work are recorded in Institute of Occupational Medicine report TM/82/4.

\section{References}

'Medical Research Council working party on research into chronic bronchitis. Report. London: Medical Research Council, 1976.

${ }^{2}$ Meade F, Saunders MJ, Hyett F, Reynolds JA, Pearl N, Cotes JE. Automatic measurement of lung function. Lancet 1965;ii:573-5.

${ }^{3}$ Cotes JE. Lung function. Oxford: Blackwell Scientific Publications, 1979:369-85.

4 Soutar CA, Copland LH, Thornley PE, et al. Epidemiological study of respiratory disease in workers exposed to polyvinylchloride dust. Thorax 1980;35:644-52.

${ }^{5}$ Mastrangelo G, Manno M, Marcer G, et al. Polyvinyl chloride pneumoconiosis: epidemiological study of exposed workers. JOM 1979;21:540-2.

- Darke CS. Vinyl chloride and the production of PVC. Proceedings of the Royal Society of Medicine 1976.

${ }^{7}$ Lange CE, Juhe S, Stein G, Veltman G. Die sogenannte Vinylchlorid-Krankheit eine berufsbedingte Systemsklerose? International Archiv Arbeitzmedizin 1974;32:1-32.

${ }^{8}$ Hunter AM, Wagner JC, Johnston N, Seaton A. Lung fibrosis in polyvinylchloride workers. Thorax 1981;36:711-2.

${ }^{4}$ Prodan L, Suciu I, Pislaru V, Ilea E, Pasou L. Experimental chronic poisoning with vinyl chloride (monochloroethane). Ann NY Acad Sci 1975;246: 159-63.

${ }^{10}$ Arnaud A, Pommier de Santi P, Garbe L, Payan H, Charpin J. Polyvinyl chloride pneumoconiosis. Thorax 1978;33:19-25. 